Liu Jia,

post-graduate student, Department of Music Art and Choreography, South Ukrainian National Pedagogical University named after K. D. Ushynsky, 4, Fontanska doroha Str., Odesa, Ukraine

\title{
PEDAGOGICAL CONDITIONS OF PREPARING MASTER'S STUDENTS MAJORING IN SINGING FOR INNOVATIVE PROFESSIONAL ACTIVITIES
}

The paper deals with the issues of preparing Master's students - future singers and voice teachers - for mastering innovative technologies in their professional activities. The relevance of the paper is determined by the fact that the above mentioned issues are currently understudied. Consequently, the author has considered scholarly literature, in which the essence and specificity of innovative technologies are characterized, as well as the essence of preparing students for innovative technologies implementation. The preparation includes the following components: the complex of psycho-pedagogical orientations determining certain forms and methods of teaching; organizational and tutorial tools of the teaching process; the complex of systemic interrelated forms and methods of pedagogical impact applied according to a certain algorithm; monitoring and correction of the obtained results, which facilitate achieving the anticipated result of training future specialists. The process of implementing innovative technologies is associated with the responsiveness of acquiring knowledge, abilities and skills in vocal art; individual choosing and interpretation of works; forming the capacity for self-analysis and self-evaluation, self-improvement in performing and teaching activities. The pedagogical conditions that facilitate students' mastering innovative technologies and their ability to apply them effectively in singer's performing and teaching activities have been substantiated. The first pedagogical condition involves providing comfortable psychological climate and style of pedagogical communication in the teaching process, i.e. factors that influence students' self-confidence, their ability to experiment, and readiness for overcoming failures. The second pedagogical condition is considered to be the level of development of students' personal qualities (emotional and volitional, intellectual qualities; determination; performance capabilities; moral traits like responsibility for vocal development of their pupils), which determine the efficiency of their preparation for innovative creative activity. The third pedagogical condition involves organization of gradual preparation of students-singers for professional innovative creativity in performing, methodical and theoretical, pedagogical and practical forms of teaching activities. It has been concluded that after implementing the above mentioned pedagogical conditions it is possible to achieve higher level of students' competence in innovative technologies; there appear more opportunities for them to improve their learning, performing and future pedagogical activities.

Keywords: vocal training, innovative technologies, pedagogical conditions, vocal performance, voice teacher.

Реиензент: д. мистецтвознавства, проф. С. В. Шип

Подано до редакиії 20.06.2016

УДК: 378.011.3-051:78

Тарас Дмитрович Пухальський, асистент кафедри музичного мистеитва, Кам'янець-Подільський національний університету імені Івана Огієнка, вул. Огієнка 61, м. Кам'янець-Подільський, Украӥна

\section{ОСОБИСТІСНА СКЛАДОВА ПРОФЕСІЙНОЇ КОМПЕТЕНТНОСТІ ВЧИТЕЛЯ МУЗИКИ}

У статті здійснено аналіз особистісної складової професійної компетентності вчителів музики та висвітлено місие $i$ роль особистісних характеристик у його професійній підготовці. Конкретизовано особистісну складову професійної компетентності учителя музики та визначено пї як сукупність індивідуально-психологічних особливостей, особистісних здібностей та особистісних якостей. Обгрунтовано фундаментальність особистісної складової у структурі професійної компетентності учителя музики.

Ключові слова: особистісні характеристики, особистісні якості, педагогічні здібності, музичні здібності, творчі здібності, учитель музики.

Постановка проблеми. Перехід освітнього процесу нашої держави на компетентнісну модель має на меті підготовку високоякісних фахівців відповідно до сучасних вимог і тенденцій на освітньому ринку. Проблема формування професійної компетентності майбутніх учителів не втрачає актуальності та утримує стійкий інтерес науковців, однак їхні погляди в окремих аспек- тах зазначеної проблематики різняться, тому і потребують подальшої наукової розробки.

Аналіз наукових досліджень і публікацій. Аналіз наукових досліджень дав можливість виділити основні підходи у визначенні професійної компетентності вчителя, які різняться за широтою розуміння самого поняття. У вузькому розумінні ком- 
петентним вважають такого учителя, який відповідально й якісно здійснює свою професійну діяльність, володіє знаннями та вміннями, нерозривно поєднаними 3 практичним досвідом, створює та розв'язує проблемні ситуації, ставить цілі та досягає ïx (Ю. Афанасьєв, В. Введенський, Е. Зеєр, І. Зязюн, Н. Нечаєв, А. Новиков, Дж. Равен та ін.). Такий підхід до компетентності педагога позбавлений індивідуального характеру, на відміну від тлумачень прихильників більш широкого розуміння професійної компетентності учителя, яке грунтується на єдності високого рівня володіння професійною діяльністю та особистісних якостей, від яких рівною мірою залежить успіх педагогічної діяльності. (О. Власова, Н. Кузьміна, А. Маркова, А. Орлов, В. Синенко, В. Сластьонін, А. Хуторський та ін.). Тому зміна акцентів у формуванні професійної компетентності вчителів музики в сторону особистісної складової позитивно відобразиться на його професійному рівні.

Науковим підгрунтям вирішення окресленої проблеми стали дослідження Л. Арчажникової, А. Бодалева, Л. Виготського, О. Власової, Г. Костюка, О. Леонтьєва, А. Маркової, О. Ростовського, В. Сластьоніна, Б. Теплова та ін. Визначення ролі та місця особистісних якостей у професійній підготовці педагогів започатковано у працях М. Амінова, О. Борденюк, Г. Вергелес, Е. Ільїна, Н. Кічук, В. Крутецького, Н. Кузьміної, С. Сисоєвої та ін. Стосовно професійної підготовки учителів музики, роль та значення їхніх особистісних характеристик у процесі формування професійної компетентності не знайшли належної наукової розробки в працях науковців, що актуалізувало наше дослідження.

Метою дослідження $є$ аналіз особистісної складової професійної компетентності вчителів музики та висвітлення місця і ролі особистісних характеристик у його професійній підготовці.

Завдання дослідження: здійснити аналіз психолого-педагогічної літератури, виокремити професійно важливі особистісні характеристики вчителя музики, визначити роль особистісних характеристик у ефективності процесу формування професійної компетентності.

Методи дослідження. В процесі дослідження використано групу теоретичних методів дослідження: засобами аналізу психолого-педагогічної літератури та засобами синтезу наукових фактів виділено професійно значущі характеристики особистості вчителя музики; методами порівняння та класифікації конкретизовано набір особистісних характеристик учителя музики.

Виклад основного матеріалу. Особистість учителя музики передусім формується в активній діяльності, в процесі якої виявляються та одночасно розвиваються особистісні якості, здібності, вміння, навички (Л. Виготський, Г. Костюк, О. Леонтьєв, С. Рубінштейн та ін.). Усі властивості особистості, виявлені чи набуті в процесі діяльності, зазнають постійних змін, інтеграції, взаємооновлення та утво- рюють складну, стійку і водночас динамічну систему психологічних властивостей учителя музики $[4$, с. 81$]$. Тому особистісну складову ми вважаємо своєрідним ядром структури професійної компетентності учителя музики та трактуємо її як органічний симбіоз природних і набутих індивідуально-психологічних особливостей, особистісних здібностей та особистісних якостей. Важливість таких особистісних характеристик у діяльності вчителя музики важко переоцінити, адже їхня наявність чи відсутність прямо впливає на результативність його діяльності як музиканта, педагога, наставника, просвітника, виконавця, керівника учнівських музично-творчих колективів.

Індивідуально-психологічні особливості учителя музики включають характеристики психофізіологічних процесів, анатомо-фізіологічні та психологічні характеристики.

Характеристика перебігу психофізіологічних процесів у кожного окремого індивіда становить природну основу формації його як особистості. «Психічні процеси - це різні форми чи види взаємодії внутрішнього та зовнішнього психічного, внаслідок чого у психіці відображаються предмети та явища» [9, с. 10]. Такі процеси є невід'ємними компонентами людської діяльності. Важливою частиною дослідження професійної схильності та професійної придатності особистості $є$ вивчення психічних процесів (сприймання, мислення, пам'яті, уваги, уяви, фантазії, емоцій та ін.), їхніх особливостей та специфіки перебігу, характерних для професії вчителя музики. Перебіг психічних процесів характеризується їхньою взаємопов'язаністю та комплексністю, тому в психології їх функціонування розглядається у формі комплексних процесів або системних дій, що слугують основою розвитку особистісних здібностей (за термінологією Б. Ананьєва): сенсомоторних (рух у поєднанні 3 відчуттями; робота виконавського апарату музиканта), перцептивних (відчуття в поєднанні з розумовими процесами; сприймання; музичне сприймання), аттенціонних (уваги), мнемічних (образної, тактильної, візуальної, інформаційної, музичної пам'яті), імажинативних (уяви і фантазії, творчості), інтелектуальних (розумових дій, педагогічного та музичного мислення, педагогічної та музичної інтуїції), комунікативних (спілкування, взаємодії учителя 3 учнями, диригента 3 колективом, виконавця з публікою).

До основних анатомо-фізіологічних показників відповідності професії вчителя музики ми відносимо фізіологічні задатки та фізичні характеристики. Задатки психологічною наукою характеризуються як «вроджені передумови розвитку здібностей особистості (анатомо-фізіологічні особливості мозку, нервової системи, аналізаторів, які обумовлюють природні індивідуальні відмінності між людьми)» [9, c. 230-233]. Успішна педагогічна діяльність передбачає наявність таких психофізіологічних задатків, як психічне здоров'я, витривалість нервової системи, стресостійкість, здатність до мобілізації і 
релаксації, моральну витримку. Фізичними характеристиками, необхідними вчителю, є фізичне здоров'я, розвинутий мовний апарат і витривалий голос. Окремою групою є фізичні характеристики, що слугують маркером у визначенні оптимального виконавського апарату майбутнього музиканта: за анатомічною будовою тіла (гортані для співаків; лицьових м'язів для духовиків; рук для диригентів, піаністів, струнників і т.д.); особливостями функціонування професійно важливих фізіологічних систем (органів слуху, дихання, м'язово-рухової системи, міміки тощо). Зауважимо, хоч більшість анатомо-фізіологічних характеристик виконавського апарату описані для музикантів різного фаху, до діяльності учителя музики це має пряме відношення, адже учитель музики виконує роль і інструменталіста, і вокаліста, і диригента.

Професійно важливими психологічними характеристиками особистості вчителя музики на основі проведеного аналізу нами визначено темперамент і характер. Для музиканта важливою властивістю темпераменту $є$ емоційна збудливість, яка $є$ системотворчою у здатності до емоційного переживання музики (музичності), музичних здібностей, експресії. Недоліки у відповідності темпераменту професії вчителя музики можуть лише певною мірою компенсуватись вольовими зусиллями, тренінгами, спеціальною підготовкою. Темперамент тісно переплітається із характером особистості. До важливих рис характеру майбутніх учителів музики у процесі професійної підготовки можна віднести старанність, працелюбність, організованість, дисциплінованість, вимогливість, відповідальність, принциповість тощо. Основою характеру $є$ спрямованість та ії складові: прагнення, уявлення, інтереси, погляди, схильності, потреби, переконання, тощо. Вони слугують формуванню мотиваційної сфери особистості вчителя музики. Наступною професійно важливою складовою характеру $\epsilon$ воля. Завдяки волі майбутній учитель музики може наполегливо працювати, постійно вдосконалюватися, відшліфовувати своє виконавство, підвищувати професійний рівень, досягати поставленої мети. Відсутність волі у характері вчителя музики проявляється через нерішучість, неспроможність відстояти свою думку, боязнь аудиторії, невпевненість у собі навіть при хорошому рівні знань, умінь та навичок. Досліджуючи психологічні властивості особистості музиканта, В. Петрушин наголошує на трьох вольових характеристиках: наполегливості (тривалому робочому навантаженню для досягнення мети), самостійності (довіра до самого себе в прийнятті рішень) та витримці (уміння керувати собою в умовах впливу негативних факторів - страху, гніву, відчаю тощо) [8, c. 291]. Ще однією важливою рисою характеру є його емоційна забарвленість, яка відображається у варіативності емоційних реакцій на явища та ситуації оточуючої дійсності, спілкування, дії тощо. Така характеристика має значення для визначення емоційного фону особистості вчителя музики, ступеня керованості своїми емоціями, здатності до емоційних переживань, емоційного відклику на музику, експресивно-виконавської діяльності. Узагальнюючи, хочемо звернути увагу на двосторонній вплив між характером учителя музики та його професійною діяльністю. Професійна діяльність учителя музики накладає свій відбиток на його особистість, поступово відшліфовуючи риси характеру. 3 іншого боку, професійна діяльність набуває ознак індивідуальності, своєрідного стилю завдяки унікальності характеру особистості.

Як і будь-яка інша професійна діяльність, музично-педагогічна засновується на певній сукупності здібностей, які повною мірою виявляють себе в безпосередній діяльності та в процесі розвитку. Більшою мірою саме здібності визначають професійну придатність особистості тим чи іншим спеціальностям. Ми неодноразово наголошували на комплексності професії вчителя музики, яка увібрала в себе безліч функцій (педагога, виконавця, теоретика, просвітника, творця, дослідника, режисера і т. д.), що унеможливлює іiі опанування без наявності природних i набутих професійних здібностей. Особистісні здібності учителя музики ми умовно можемо розділити на загальні та спеціальні здібності.

До базових характеристик особистості учителя музики ми відносимо загальні здібності людини, які можуть в певній мірі виявлятися в усіх видах піi діяльності (здібності до навчання, загальні розумові здібності, здібності до праці тощо). Похідними таких здібностей є вміння загального характеру, необхідні в кожній сфері професійної діяльності: уміння усвідомлювати завдання, планувати й організовувати їх виконання, використовуючи наявні в досвіді людини засоби, розкривати зв'язки тих речей, яких стосується діяльність, оволодівати новими прийомами роботи, переборювати труднощі на шляху до мети.

Спеціальні здібності для здійснення музичнопедагогічної діяльності ми умовно розділили на три групи: музичні, педагогічні та творчі.

Музичні здібності є основою музично-практичної підготовки вчителя музики. Особливо важливим блоком музичних здібностей є музичність, яка є синтезом музичного слуху та здатності до емоційного переживання музики. Відомий психолог Б. Теплов виділив у структурі музичності три основні музичні здібності: ладове відчуття (здатність емоційно розрізняти ладові функції, відчувати звуковисотний рух), слухове уявлення (запам'ятовування та відтворення на слух мелодій), музично-ритмічне відчуття (здатність відчувати емоційну виразність музичного ритму i точно відтворювати його) $[11$, с. 26-27]. Основною ознакою музичності науковець вважає здатність до переживання музики у процесі сприймання та аналізу художнього змісту музичного твору.

Окрім музичного слуху, музичної пам'яті та ритмічності, здатність до емоційних переживань $є$ 
професійно необхідною якістю учителя музики. Особливу увагу емоційній складовій діяльності музиканта приділив В. Медушевський, який вважає, що емоційність проявляється, 3 одного боку, в умінні пройнятися переживаннями, які входять до музичного образу музичного твору, 3 іншого - передати їх як власні переживання під час виконання [7, с. 26].

Характерною особливістю музичних здібностей $\epsilon$ те, що міра їхнього розвитку виявляється лише в активній формі музичної діяльності, в процесі якої на основі розвитку виявлених здібностей в поєднанні 3 особистісними особливостями виявляються і вдосконалюються нові здібності. Наприклад, виконавські здібності формуються на основі базових музичних здібностей, інтелектуальних, емоційних (експресивних) та вольових даних особистості та вдосконалюються впродовж усього періоду діяльності. Щоб дослідити музичні здібності, потрібен тривалий період спостерігання за особистістю. Цей факт ставить перед системою освіти загалом та конкретним викладачем додаткові вимоги із забезпечення індивідуального підходу та особистісно-орієнтованих технологій у розвитку музичних здібностей, від рівня розвитку яких напряму залежить ефективність засвоєння професійних знань, темпи розвитку музичних вмінь та навичок, що є ключовими складовими професійної компетентності учителя музики.

У психолого-педагогічній літературі питання педагогічних здібностей та їхнього професійного значення у підготовці майбутніх учителів тривалий період викликало стійкий науковий інтерес і хоч думки дослідників 3 цього питання не відзначаються суттєвою суперечливістю, єдина класифікація педагогічних здібностей науці ще не відома. Дослідження педагогічних здібностей провела $\mathrm{H}$. В. Кузьміна, яка визначає їх як індивідуальну чутливість особистості до об'єктів, засобів і продуктів педагогічного процесу. Запропонована науковцем система педагогічних здібностей відображає основні сторони педагогічної діяльності: гностичні (знання та вміння в педагогічній системі), проектувальні (стратегії та засоби впливу на учнів), конструктивні (організація ефективного навчально-виховного процесу), комунікативні (встановлення педагогічно доцільних взаємин із учнями) та організаторські здібності (ефективний розподіл ресурсів у різних видах діяльності, створення оптимального навчальновиховного середовища).

Схожими класифікаціями педагогічних здібностей вчителя 3 невеликими доповненнями стали розробки В. Крутецького (дидактичні, академічні, перцептивні, мовленнєві, організаторські, авторитарні та комунікативні здібності), С. Смирнова (гностичні, конструктивні, організаційні та комунікативні здібності), О. Щербакова (перцептивні, дидактичні, комунікативні, конструктивні, експресивні, організаційні здібності). М. Амінов педагогічні здібності розглядає як індивідуальні риси, які дають змогу відрізнити одного учителя від іншого, визначити їх переваги у педагогічній діяльності. Дослідник до вищезапропонованих здібностей додає специфічні здібності: емпатії (розпізнавання внутрішніх станів учня), відчуття такту (регулювання своєї діяльності відносно переживань учнів), відчуття причетності (контроль вибраного алгоритму поведінки відносно учня) [1]. Така варіативність педагогічних здібностей у працях науковців вкотре відображає, наскільки широкий спектр здібностей необхідний учителеві для продуктивної професійної діяльності.

У творчій діяльності великого значення набувають особистісні відмінності, індивідуальність та наявність спеціальних здібностей до такої діяльності - творчих здібностей. Трактування творчих здібностей в науковій літературі неоднозначне. Це зумовлено, на нашу думку, специфікою кожної окремої професії у плані здійснення творчої діяльності. В діяльності вчителя музики творчі здібності носять нерозривно пов'язані риси педагогічної та музичної творчості. Це вказує на те, що творчі здібності вчителя музики є важливим структурним елементом професійної діяльності, а відтак і професійної компетентності.

3 точки зору О. Леонтьєва, С. Рубінштейна та Б. Теплова, творчі здібності є особливими властивостями людини, що виявляються в певній діяльності та $€$ результатом оволодіння знаннями, вміннями і навичками, необхідними для певного виду творчої діяльності. Творчі здібності в поєднанні 3 психологічними особливостями формують риси творчої особистості, ознаки якої виділяє А. Маркова: здатність помічати альтернативи, піддавати сумніву на перший погляд очевидне, уникати поверхневих формулювань, вміння водночас проникати в проблему та відриватися від реальності, бачити перспективу, здатність бачити проблему під іншим кутом, відмова від авторитетів, категоричності, готовність відійти від традиційного в пошуках нового [6, с. 48]. Схожі ознаки в науковій літературі пов'язуються 3 креативністю, яку часто ототожнюють із творчими здібностями.

Г. Вергелес творчі здібності розглядає в плані широти застосувань і виділяє загальні та спеціальні творчі здібності [2, с. 11]. Загальні творчі здібності характеризуються універсальністю та реалізуються в різних видах діяльності, спеціальні - забезпечують успіх у специфічних діяльностях (музичній, педагогічні, акторській, образотворчій, технічній, літературній, науковій тощо). До загальних творчих здібностей автор відносить: варіативність (генерування ідей, численних оригінальних способів розв'язання проблем), гіпотетичність (будування та обгрунтування гіпотез), імпровізацію (здійснення діяльності на основі інтуїції) та здатність до переносу (застосування знань, вмінь і досвіду однієї галузі діяльності в іншій) [2, с. 13-16].

Творчі здібності, необхідні в професійній діяльності учителя музики, ми вважаємо органічною 
єдністю та пропонуємо умовно структурувати за сферою застосування: у педагогічній, мистецькій та дослідницькій творчості.

Н. Кічук вважає педагогічну творчість однією 3 найважливіших сторін професії сучасного учителя. Автор відзначає такі важливі риси педагогічної творчості: суб'єктивну свободу вибору дій, самоаналіз та оцінку своєї праці, інноваційність, гуманізм, тощо [3, c. 20]. Педагогічну творчість С. Сисоєва характеризує за специфікою психічних процесів: альтернативність, дивергентість та точність мислення, готовність та асоціативність пам'яті, цілісне і синтетичне сприйняття, пошуково-перетворюючий стиль мислення $[10$, с.152153].

На думку О. Апраксіної, Л. Арчажнікової, О. Борденюк, у мистецькій творчій діяльності творчі здібності особливо підсилюються та проявляються в різних формах шляхом синтезу з музичними та іншими здібностями. Творчі здібності мистецького напряму (музичного, акторського, естетичного, тощо) особливо відзначаються інтуїтивним та експресивним характером.

Дослідницькими здібностями ми вважаємо ті, що забезпечують успішний науковий пошук й упровадження в практику ефективних методів і прийомів навчання та виховання учнів, професійного вдосконалення. Дослідницька творчість учителя музики характеризується здатністю до нових ефективних методів педагогічного впливу, детального спостереження за навчальним процесом та його аналізу, експериментальної педагогічної діяльності, втілення оригінальних і новаторських педагогічних ідей. Результатами дослідницької творчості можуть стати наукові статті, методичні посібники, інноваційні проекти тощо.

Стосовно комплексу здібностей учителя музики, хочемо зазначити, що усі здібності нерозривно поєднані між собою та є взаємодоповнюючими, тому здійснений нами поділ має умовний характер. В освітній практиці часто зустрічаються випадки, коли у студента одні здібності розвинені краще на тлі інших. На думку Е. Ільїна, можна компенсувати недостатність окремих здібностей іншими більш розвиненими, що дає можливість досягнути успіху в професійній діяльності навіть при відносній слабкій розвиненості здібностей $[5$, с. 543$]$. Цей процес стає можливим завдяки наполегливій, систематичній i кропіткій праці над собою.

Особистісні якості майбутнього учителя музики, які впливають на якість здійснення професійної діяльності, ми умовно розділили за загальним i професійним значенням. Особистісні якості загального значення: гуманізм, культурність, відповідальність, справедливість, чесність, порядність, стриманість, толерантність, доброзичливість, чуйність,

\section{ЛІТЕРАТУРА}

1. Аминов Н. А. Диагностика педагогических способностей / Н. А. Аминов. - М. : Институт практической психологии, 1997. - 80 с. принциповість, гідність, патріотизм, тощо; професійного значення: любов до дітей, здатність до емпатії, працездатність, працелюбство, організованість, дисциплінованість, наполегливість, об'єктивність, вимогливість, тактовність, сміливість, самостійність, ініціативність, цілеспрямованість, мобільність, активність, спостережливість, ерудованість, винахідливість, захопленість своєю справою, самокритичність, артистизм, емоційність, музичний смак тощо.

Підсумовуючи весь комплекс згаданих нами особистісних характеристик (індивідуальнопсихологічних особливостей, здібностей та якостей особистості), звертаємо увагу на те, що професійну компетентність учителя музики ми розглядаємо виключно як цілісне утворення, тому особистісну складову умовно виокремлено нами в особистісний компонент, який тісно взаємодіє 3 іншими компонентами структури професійної компетентності вчителя музики (когнітивним, діяльнісним та акмеологічним). Взаємозв'язок із когнітивним компонентом проявляється у залежності ефективності засвоєння знань від особистісних здібностей та у здатності знань до впливу на особистість учителя музики, його якості та ціннісні орієнтації. У співвідношенні особистісного та діяльнісного компонентів виявляються особистісні здібності, таланти, якості до безпосередньої професійної практики та загалом професійна придатність. Професійна діяльність також несе свій вплив на особистість учителя музики, формуючи якості, необхідні для іiі успішного виконання, тим самим актуалізує важливість виховної роботи у процесі формування професійної компетентності. Взаємозв'язок особистісного та акмеологічного компонентів проявляється у здатності до професійного зростання на основі особистісних задатків до самовдосконалення, $з$ іншого боку - вдосконалення особистісних якостей за допомогою рефлексивних процесів, умотивованості та саморегуляції.

\section{Висновки та перспективи подалыших} досліджень. Отже, на основі детального аналізу специфіки професійної підготовки, професійної діяльності та специфіки музично-педагогічної діяльності учителів, спираючись на проведений аналіз досліджень науковців, ми визначили основою професійної компетентності вчителя музики його особистісні характеристики, які, в свою чергу, визначають рівень професійної придатності, характер i результативність процесу формування професійної компетентності вчителя музики. Подальше дослідження вбачаємо у конкретизації структурних компонентів професійної компетентності вчителя музики.

2. Вергелес Г. И. Развитие общих творческих способностей как проблема педагогической психологии / Вергелес Г. И. // Известия Российского государ- 
ственного педагогического университета имени А. И. Герцена. - СПб., 2009. - №100. - С.7-18.

3. Кичук Н. В. Формування творчої особистості вчителя / Н. В. Кичук. - К. : Либідь, 1991. - 96 с.

4. Леонтьев А. Н. Деятельность. Сознание. Личность / А. Н. Леонтьев. - М. : Политиздат, 1995. - 304 с.

5. Маклаков А. Г. Общая психология : [учебник для вузов] / А. Г. Маклаков. - СПб. : Питер, 2008. - 583 с.

6. Маркова А. К. Психология труда учителя / А. К. Маркова. - М. : Просвещение, 1993. - 192 с.

7. Медушинский В. О. О закономерностях и средствах художественного воздействия музыки / В. О. Медушинский. - М. : Музыка, 1979. - 319 с.

\section{REFERENCES}

1. Aminov, N. A. (1997). Diagnostika pedagogicheskikh sposobnostey [Diagnostics of pedagogical capabilities]. Moscow: Institut prakticheskoy psikhologii [in Russian].

2. Vergeles, G. I. (2009). Razvitie obschikh tvorcheskikh sposobnostey kak problema pedagogicheskoy psikhologii [The development of general creativity as a problem of educational psychology]. Izvestiya Rossiiskogo gosudarstvennogo pedagogicheskogo universiteta imeni A. I. Gertsena - Izvestia: Herzen University Journal of Humanities and Science, 100, 7-18. St.Petersburg [in Russian].

3. Kychuk, N.V. (1991). Formuvannia tvorchoi osobystosti vchytelia [The formation of creative personality of a teacher]. Kyiv: Lybid [in Ukrainian].

4. Leontyev, A. N. (1995). Deyatelnost. Soznanie. Lichnost [Activities. Consciousness. Personality]. Moscow: Politizdat [in Russian].

5. Maklakov, A. G. (2008). Obschaya psikhologiya [General psychology]. St. Petersburg: Piter [in Russian].

8. Петрушин В. И. Музыкальная психология / В. И. Петрушин. - М. : Академический проект, 2008. $400 \mathrm{c}$.

9. Сергєєнкова О. П. Загальна психологія : [навч. посіб.] / О. П. Сергєєнкова, О. А. Столярчук, О. П. Коханова, О. В Пасєка. - К. : Центр учбової літератури, 2012. - 296 с.

10. Сисоєва С. О. Основи педагогічної творчості : підручник / С. О. Сисоєва. - К. : Міленіум, 2006. $346 \mathrm{c}$.

11. Теплов Б. М. Избранные труды : в 2 т. / Б. М. Теплов : [ред. - Н.С. Лейтес]. - М. : Педагогика, 1985. - T.1. -329 c.

6. Markova, A. K. (1993). Psikhologiya truda uchitelya [Psychology of teacher's work]. Moscow: Prosveshchenie [in Russian].

7. Medushinskiy, V. O. (1979). O zakonomernostyakh i sredstvakh khudozhestvennogo vozdeistviya muzyki [About common factors and means of artistic effects of music]. Moscow: Muzyka [in Russian].

8. Petrushin, V. I. (2008). Muzykalnaya psikhologiya [Music psychology]. Moscow: Akademicheskii proekt [in Russian].

9. Serhieienkova, O. P., Stoliarchuk, O. A., Kokhanova, O. P. \& Pasieka, O. V. (2012). Zahalna psykholohiia [General psychology]. Kyiv: Tsentr uchbovoi literatury [in Ukrainian].

10. Sysoieva, S. O. (2006). Osnovy pedahohichnoi tvorchosti [Fundamentals of pedagogical creativity]. Kyiv: Milenium [in Ukrainian].

11. Teplov, B. M. (1985). Izbrannye trudy [Selected works]. (Vols. 1). Moscow: Pedagogika [in Russian].

Тарас Дмитриевич Пухальский, ассистент кафедры музыкального искусства, Каменеи-Подольский национальный университет имени Ивана Огиенко, ул. Огиенко, 61, г. Каменеи-Подольский, Украина

\section{ЛИЧНОСТНАЯ СОСТАВЛЯЮЩАЯ ПРОФЕССИОНАЛЬНОЙ КОМПЕТЕНТНОСТИ УЧИТЕЛЯ МУЗЫКИ}

В статье осуществлен анализ личностной составляющей профессиональной компетентности учителей музыки и освещены место и роль личностных характеристик в его профессиональной подготовке. Личностная составляющая профессиональной компетентности учителя музыки определена как совокупность индивидуально-психологических особенностей, личностных способностей и личностных качеств. Индивидуально-психологические особенности учителя музыки представлены как совокупность профессионально важных психофизиологических (восприятие, мышление, память, внимание, воображение, фантазия, эмоции и др.), анатомо-физиологических (здоровье, выносливость нервной системы, стрессоустойчивость, способность к мобилизации и релаксации, анатомическое строение тела, особенности функционирования физиологических систем органов слуха, дыхания, мышечно-двигательной системы, мимики и т.д.) и психологических характеристик (особенности темперамента и характера). Выделены профессионально значимые личностные способности учителя музыки, которые автором условно разделены на способности общего и специального значения. Установлено, что общие способности проявляются во всех видах человеческой деятельности (способности к обучению, общие умственные способности, способности к труду и т.д.) и имеют общее профессиональное значение. Специальными способностями учителя музыки являются музыкальные (музыкальный слух, музыкальность, музыкальная память, чувство ритма, музыкальное мышление, способность к эмоциональному переживанию музыки), педагогические (гностические, конструктивные, коммуникативные, перцептивные, авторитарные, экспрессивные, дидактические, академические, организаторские и др.) и творческие способности (педагогические, художественные, исследовательские). Описан комплекс личностных качеств, необходимых в профессиональной деятельности учителю музыки (общего и специального значения). Обоснована фундаментальность личностной составляющей в структуре профессиональной компетентности учителя музыки и описана ее взаимосвязь с другими структурными компонентами (когнитивным, деятельностным, акмеологическим). Результаты исследования 
свидетельствуют о решающей роли личностных характеристик в процессе формирования профессиональной компетентности учителя музыки, в его результативности и в определении уровня профессиональной пригодности.

Ключевые слова: личностные характеристики, личностные качества, педагогические способности, музыкальные способности, творческие способности, учитель музыки.

\author{
Taras Pukhalskyi, \\ assistant lecturer, Department of Music Arts, \\ Kamianets-Podilskyi Ivan Ohienko National University, \\ 61, Ohienko Str., Kamianets-Podilskyi, Ukraine
}

PERSONAL COMPONENT OF MUSIC TEACHER'S PROFESSIONAL COMPETENCE

The paper deals with the analysis of personal component of music teachers' professional competence; the place and the role of personal characteristics in teacher's professional background are described. Personal component of music teacher's professional competence is defined as a set of individually psychological features, personal capabilities and personal qualities. Individually psychological features of a music teacher are represented as a set of professionally significant psycho-physiological (perception, thinking, memory, imagination, fantasy, emotions, etc.), anatomical and physiological (health, nervous system tolerance, resilience to stress, the ability for mobilization and relaxation, anatomical organization of a body, features of the functioning of physiological systems of hearing and respiratory organs, neuromuscular system, facial expression, etc.) and psychological characteristics (features of temperament and temper). The author has divided professionally significant personal capabilities of a music teacher into general and specific ones. General capabilities are manifested in all kinds of human activity (learning capability, general mental capabilities, capacity for work, etc.) and have general professional significance. Specific capabilities of a music teacher include ability for music (ear for music, musical sense, musical memory, sense of rhythm, musical thinking, ability for music emotional experiencing), pedagogical capabilities (gnostical, practical, communicative, perceptive, authoritative, expressive, didactic, academic, organizational, etc.) and creativity (pedagogical, artistic and research capabilities). The author has also described a set of personal qualities necessary for music teacher's work (general and specific ones) as well as interrelation between personal component in the structure of music teacher's professional competence and other structural components (cognitive, pragmatic and acmeological). Results of the study have proven the critical role of personal characteristics in the process of forming music teachers' professional competence, in its effectiveness and in determining the level of professional aptitude. teacher.

Keywords: personal characteristics, personal qualities, pedagogical capabilities, ability for music, creativity, music

Подано до редакиії 20.06.2016

Рецензент: д. пед. н. В. М. Лабунеиьь

УДК: 378.6.147.014:656.61

Тетяна Василівна Сирбу, викладач англійської мови кафедри англійської мови №1, Національний університет "Одеська морська академія», вул. Дідріхсона, 8, м. Одеса, Украӥна

\title{
ТЕОРЕТИЧНІ ЗАСАДИ ФОРМУВАННЯ \\ ГОТОВНОСТІ МАЙБУТНІХ СУДНОВОДІЇВ ДО ВИКОРИСТАННЯ КОПІНГ-СТРАТЕГІЙ У ПРОФЕСІЙНІЙ ДІЯЛЬНОСТІ
}

У статті проаналізовано окремі педагогічні та психологічні підходи до визначення феноменів «готовність» та «діяльність». Розкрито сутність поняття професійної діяльності та представлено ї̈ компонентну структуру. Висвітлено проблему готовності до професійної діяльності, зокрема розглянуто психологічну готовність до професійної діяльності. Визначено умови формування готовності майбутніх судноводіїв до використання копінг-стратегій у професійної діяльності.

Ключові слова: діяльність, готовність, професійна діяльність, готовність до професійної діяльності, копінг-стратегія.

Постановка проблеми. 3 розвитком мореплавства відбулися певні зміни у роботі судноводіїв. 3 першого погляду, можна вважати умови перебування на судні більш безпечними, але цей погляд не враховує суспільні та людські проблеми морського плавання, які необхідно вирішити. Ми вважаємо, що у майбутньому залишаться труднощі, пов'язані з подоланням великих відстаней, життям та працею у складі невеликого колективу за умов обмежених комунікативних можливостей, силами стихій, зміною кліматичних умов та іншими об'єктивними обставинами. Натомість, багато чого можна покращити та спростити за умов розумного впровадження 